\title{
Quantification and evaluation of chemical footprint of woollen textiles
} DOI: 10.35530/IT.072.01.1773

\section{ABSTRACT - REZUMAT}

\section{Quantification and evaluation of chemical footprint of woollen textiles}

The chemical pollutants discharged in the production processes of textile products cause severe impact on the environment. The chemical footprint (ChF) methodology provides a new way to quantify the toxicity impacts caused by chemical pollutants. ChF does well in identifying priority chemical pollutants and helping enterprises to select greener chemicals to reduce the environment impacts. In this study, the ChF of woollen yarn were assessed with the data that collected from the production processes. The results showed that the ChF of dyeing process (4.10E+06 I) accounted for the largest proportion, because a large number of auxiliaries were used in the dyeing process to prevent uneven dyeing and colour difference, followed by scouring $(7.79 E+05 \mathrm{I})$ and finishing $(8.11 E+03 \mathrm{I})$. Among all the discharged chemical pollutants, polyoxyethylene nonyl phenyl ether $(1.37 E+06$ l) caused the most ecotoxicity severe impact on the environment due to its high bioaccumulation and high toxicity to ecosystem, followed by sulfuric acid (1.03E+06 I). Sodium chloride and hydrogen peroxide were the two substances that caused the least environmental load. The overall uncertainty caused by toxicity prediction data accounting for $20.2 \%$ of the total ChF, and the uncertainty of the scouring process was the most. The results are referable for wool textiles producers to enhance the textile chemicals management.

Keywords: chemical footprint, assessment of mean impact, dyeing and finishing, environment load, woollen yarn

\section{Cuantificarea și evaluarea amprentei chimice a materialelor textilelor din lână}

Poluanții chimici rezultați din procesele de producție a produselor textile provoacă un impact sever asupra mediului. Metodologia amprentei chimice (ChF) oferă o nouă modalitate de a cuantifica impactul toxicității cauzate de poluanții chimici. ChF se ocupă de identificarea cu prioritate a poluanților chimici și ajută întreprinderile să selecteze substanțe chimice ecologice, pentru a reduce impactul asupra mediului. În acest studiu, ChF-ul firelor de lână a fost evaluat cu datele colectate din procesele de producție. Rezultatele au arătat că ChF-ul procesului de vopsire (4.10E + 06 I) a reprezentat cea mai mare proporție, deoarece un număr mare de auxiliari au fost utilizați în procesul de vopsire pentru a preveni vopsirea neuniformă și diferența de culoare, urmat de spălare (7.79E + 05 I) și finisare (8.11E + 03 I). Dintre toți poluanții chimici rezultați, eterul polioxietilen nonilfenilic $(1,37 E+06$ I) a cauzat cel mai sever impact de ecotoxicitate asupra mediului, din cauza bioacumulării sale ridicate și a toxicității ridicate pentru ecosistem, urmat de acidul sulfuric $(1,03 E+06$ I). Clorura de sodiu și peroxidul de hidrogen au fost cele două substanțe care au cauzat cel mai mic impact asupra mediului. Incertitudinea generală cauzată de datele de predicție a toxicității a reprezentat 20,2\% din totalul ChF, iar incertitudinea procesului de spălare a fost cea mai mare. Rezultatele sunt disponibile pentru producătorii de materiale textile din lână pentru a îmbunătăți gestionarea produselor chimice textile.

Cuvinte-cheie: amprentă chimică, evaluarea impactului mediu, vopsire și finisare, impact asupra mediului, fire de lână

\section{INTRODUCTION}

Textile industry is one of the most important manufacturing industries in the world with long industrial chain and many subsectors. In 2017, the global production of fibers exceeded 90 million tons and the global trade in textiles and apparel exceeded 745.9 billion dollars [1-2]. Chemicals play a vital role in the production of textiles. In 2018, the global market size of textile chemicals exceeded US\$10 million, and thousands of textile auxiliary agents were widely used in various sub-industries of the textile industry [3]. Taking China as an example, the world's largest producer of textiles, more than 700 kinds of dyes and 1500 kinds of textile auxiliary agents are daily used [4]. The uncombined dyes and auxiliaries are discharged into the environment with waste water, waste gas and waste residue [5]. These discharged dyes and auxiliaries, even contain harmful chemicals such as heavy metals and nonylphenol, cause serious impact on the environment [6].

Chemical footprint (ChF) was first proposed formally by Panko and Hitchcock in 2011 [7]. ChF provides a new perspective to quantify and evaluate the effect on ecosystem caused by chemical pollutants. This solves the problem of inadequate chemical representation in traditional footprint methodology [8]. The Characteristic factor method based on USEtox model to show the environmental load in the form of Comparative Toxic Units (CTU) were widely used in ChF assessment. For example, Bjørn et al. [8] calculated the ChF of agriculture in Europe and Denmark, 
and showed the distribution of ChF in time and space respectively. Sörme et al. [9] used European Pollutant Release and Transfer Register as a database to calculate the ChF of 54 substances discharged into the air and water in the national region of Sweden. The definition of ChF based on CTU reflects the toxic effect of chemicals with the help of integrated model in the field of environment, and comprehensively reflects the potential impact of chemical emissions on species. On the premise of knowing the time period of environmental load, the ChF based on CTU can be transformed into volume form [10]. Based on the concept of safe operating space, another concept of ChF was defined as the ratio of required to available water volumes in a given geographic area [11]. The discussion of the challenges in improving the relationship between security boundaries and natural thresholds providing ideas for later researchers. With the help of volume-weighted mixture toxic pressure, Zijp et al. [12] calculated the ChF of 630 organic chemicals in Europe and pesticides in the rivers Rhine, Meuse, and Scheldt (RMS). The results showed that the ChF of organic was within the natural carrying capacity of the area, while the ChF of pesticides was far beyond the natural carrying capacity of RMS. Du [13] introduced the assessment of mean impact (AMI) method into ChF and defined the chemical pollution index. Based on the ecotoxicity threshold of freshwater, $21 \%$ of China's basin ChF exceed their available freshwater resources by calculated 36 antibiotics which are commonly detected in China's river basins. The essence of this definition of ChF was to check whether the environment in the study area had enough dilution capacity to ensure the ecosystem safety [12]. This can reflect the differences between different regions, and the quantified results were intuitive enough to facilitate the popularization of the theory and understanding of public cognition.

Wool textiles are deeply loved by consumers because of their excellent wearing properties. The statistics show that the global wool textile production exceeded 1.16 million tons in 2017 [1]. The processing (e.g., scouring, dyeing, finishing) of wool textiles consumes large quantities of chemicals and discharges high concentration waste water that contains many kinds of chemical pollutants [14]. Nevertheless, there is negligible literature published on the assessment of impacts caused by the discharged chemical pollutants in the production of wool textiles. Therefore, we aim to investigate the potential ecotoxicity impacts of woollen yarn production with $\mathrm{ChF}$ methodology.

In our current study, we applied ChF methodology to quantify the ChF of woolen yarn. Then the impacts caused by chemical pollutants discharged in the production processes were analysed and discussed. What distinguishes this study is that it can provide a specific reference for wool textiles producers to reduce the environmental impacts and carried out sustainable production with green textile chemicals.

\section{EXPERIMENTAL APPROACH AND DATA}

\section{Experimental approach}

The AMI is a method used to quantify the toxic effects of chemical pollutants, which has the characteristics of compatibility of acute and chronic toxicity data [15]. In contrast to the character factor method, which requires highly integrated USEtox model, the AMI method does not need to rely on limited characteristic factors for accounting. At least three groups of organisms (typically one plant, one invertebrate, and one vertebrate) are selected to represent the three basic nutrition levels in the food chain during the average toxicity assessment process according to AMI method. This means that the AMI method is more feasible in calculating the ChF of new chemicals.

The calculation results of AMI method, which show the environmental load in the form of volume, are more intuitive and convenient for comparison with the environmental space in the follow-up study.

The ChF of a product based on AMI method can be calculated as:

$$
C h F=\sum_{i}^{n} \frac{C_{W i}}{H C_{5}(N O E C)_{i}} \cdot V
$$

where $V$ (in I) is the volume of chemical pollutants that discharged into the water body. $C_{W i}$ (in $\mathrm{g} / \mathrm{l}$ ) is the exposure concentration of substances $i$ in water phase. $\mathrm{HC}_{5}(\mathrm{NOEC})_{i}$ (in $\left.\mathrm{g} / \mathrm{l}\right)$ is the safety threshold of aquatic ecosystem.

$C_{W i}$ can be regarded as the steady-state concentration distributed in the natural water body of the study area after its fate. It can be calculated as:

$$
C_{W i} \cdot V=F_{W i} \cdot Q_{i}
$$

where $F_{W i}$ is the mass proportion of substance $i$ in the water phase after its fate (dimensionless), $Q_{i}$ (in g) - the emission quality of substance $i$.

To improve the feasibility of accounting, convert $H_{5}(N O E C)_{i}$ to $H_{50}\left(E C_{50}\right)_{i}$ whose data is relatively easy to obtain, $H C_{50}\left(E C_{50}\right)_{i}$ can be calculated as:

$$
H C_{50}\left(E C_{50}\right)=\gamma \cdot 10^{2.94 \beta} \cdot H C_{5}(\text { NOEC })
$$

where $\mathrm{HC}_{50}\left(E C_{50}\right)_{i}$ is the concentration value corresponding to $50 \%$ of the potentially affected fraction of species on the curve of species sensitivity distribution based on $E C_{50}$ fitting, and $\log H_{5}\left(E C_{50}\right)$ is approximately equal to that of $\log E C_{50} \cdot \gamma$ is equal to 9.8 [16], and $\beta$ is equal to 0.4 [17].

\section{System boundary and data}

The system boundary in this paper was from raw wool to dyed yarn, as shown in figure 1. The whole production process from wool scouring to dyeing was in one enterprise. In this study, only dyestuffs and auxiliaries (e.g., detergent, bases, bleach, levelling agent, smoothing agent etc.) that direct consumed in the production process of coloured yarn were considered for ChF calculation. The data of discharged chemical pollutants in the accounting inventory was provided by the manufacturing enterprise. Toxicity 


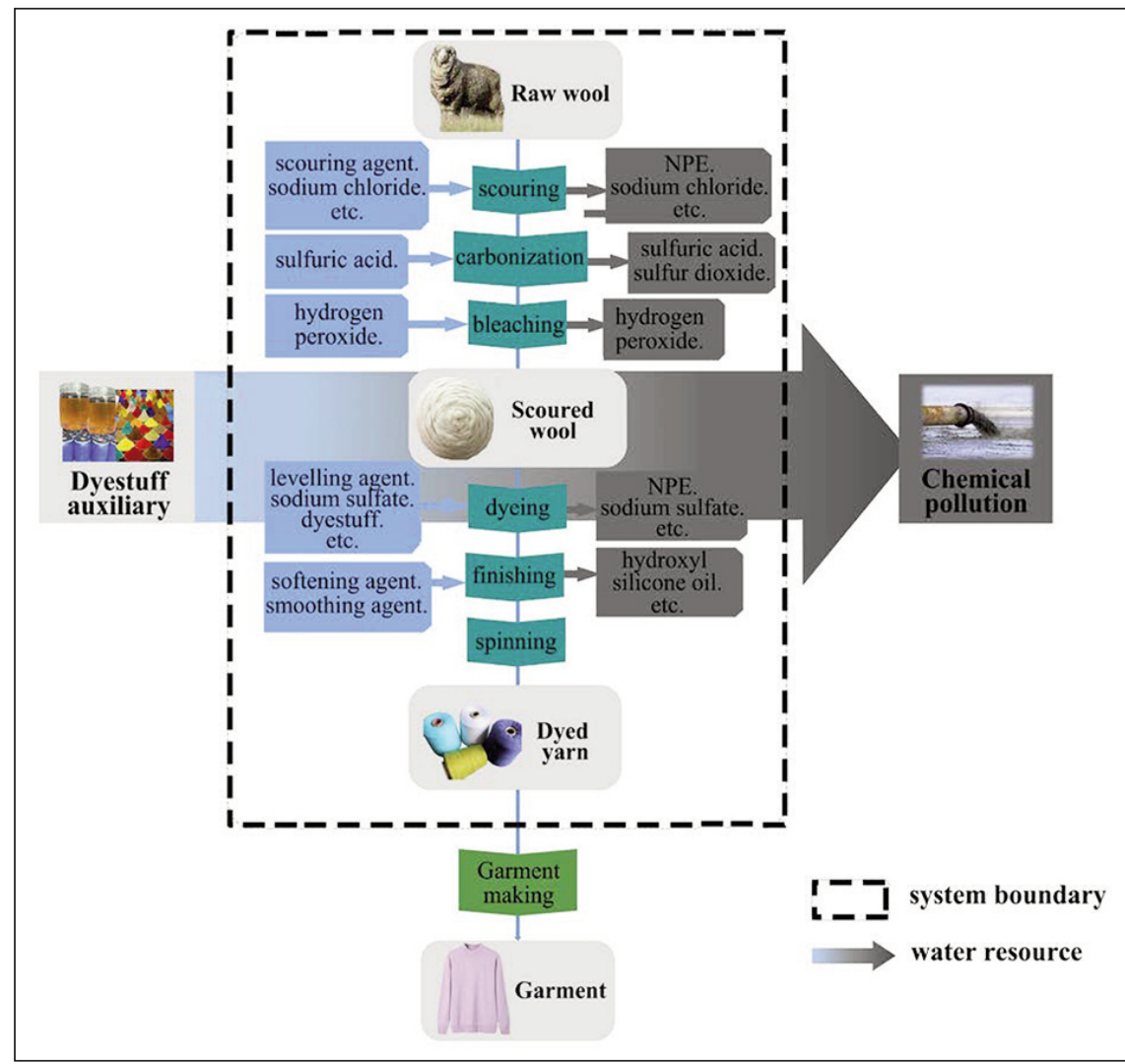

Fig. 1. The system boundary of dyed woolen yarn combine the dyes before they are absorbed by the fiber, but also pull the dye from the excessively dyed part of the fiber back into the dye bath and transfer it to the insufficiently dyed part of the fiber. Therefore, a huge amount of levelling agent is used in the dyeing process to control the dyeing speed and transfer the dyes, which is the main reason for the great contribution of the dyeing process to the environmental load [19]. This process also requires a large amount of acid solution which maintains an acidic environment, to ensure that functional chemicals such as acid dyes can bind to the amino groups in the wool fiber molecules [20].

The main reason for the great environmental impact of the scouring process is that the ecological toxicity and dosage of the scouring agent used in the process are relatively large. In the scouring process, the experimental data of chemical substances were mainly collected from USEtox model and Pesticide Action Network Pesticide database (http://www.pesticideinfo.org). A few toxicity data that cannot be collected from the two sources were predicted by quantitative structure activity relationships (QSAR) model which approximating the often complex relationships between chemical properties and biological activities of compounds [18]. The functional unit in this study was 1 ton of dyed woollen yarn.

\section{RESULTS AND DISCUSSION}

Figure 2 shows the calculated ChF of each production process. From figure 2 it can be seen that the ChF of 1 ton of dyed woollen yarn was approximately $4.89 \mathrm{E}+06 \mathrm{l}$. The dyeing process contributes the most to ecological toxicity of the dyed yarn with a result of $4.10 \mathrm{E}+06 \mathrm{I}$, followed by scouring $(7.79 \mathrm{E}+05 \mathrm{I})$. The ecotoxicity effects caused in the finishing, carbonization, and bleaching stage were much smaller than those of the above two processes.

In the dyeing process, because the scale layer on the surface of wool is compact and hydrophobic, and given the difference of wool fibers itself, the affinity of wool fibers to dyes is different, which can easily lead to uneven dyeing and colour difference between hair tips and roots [19]. The levelling agent can not only raw wool is washed to remove the non-wool contaminants (natural fats, sweats and other impurities) [21]. Sweat and sand impurities can be removed physically, while natural fats are emulsified by scouring agent and pass into suspension. A large quantity of sulfuric acid is used in the carbonization process in order to separate the plant impurities from raw wool [22]. As the main by-product of carbonization process, sulphur dioxide has undesirable effects on the environment [23]. However, the auxiliaries used in the finishing, carbonization, and bleaching processes and the

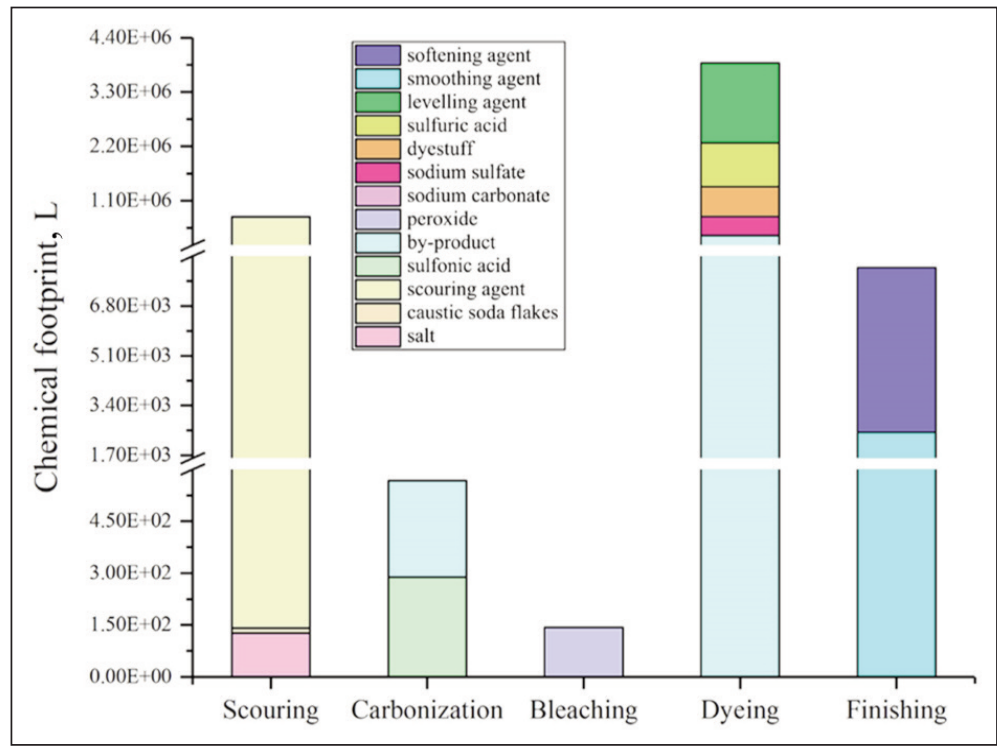

Fig. 2. ChF of process chain segment of dyed woolen yarn 
by-products produced in the production process are relatively less toxic, and the types of chemical pollutants contained in the auxiliaries used are relatively less. Therefore, the ChF of these three processes account for a small proportion of the total ChF.

Among all the discharged chemical pollutants, polyoxyethylene nonyl phenyl ether (NPE) was the most ecotoxicity to the environment. The ChF of NPE was approximately $1.37 \mathrm{E}+06 \mathrm{I}$, accounting for $28 \%$ of the total ChF. The ChF of sulfuric acid was the second largest, accounting for $21 \%$ of the total ChF.

OctaphenylPolyoxyethyiene and sodium sulphate also caused considerable ecotoxicity impacts. Sodium chloride and hydrogen peroxide were the two substances the caused the least environmental load in this study.

In this case study, NPE mainly comes from levelling and scouring agents. Although its distribution in the water phase after fate is relatively low, NPE belongs to a class of environmental estrogens, which means that it affects the sexual development of organisms and shows toxicity to the reproductive system [24]. Moreover, nonylphenol, the metabolite of NPE after biodegradation, possessed simultaneously estrogenic activities and mutation effects, which easily accumulates in organisms due to its high fat solubility and difficult degradation, thus having a serious impact on the environment [25-26]. In order to improve the product's pigmentation effect, a lot of inorganic salts are needed in the dyeing process. The retarding effect of sodium sulphate in the dyeing process is similar to that of levelling agents. Sulphates have higher fixation rates than anions in dyes, which primarily binds to amino groups in wool fibers. Even though the ecotoxicity of sodium sulphate per unit dose is two orders of magnitude less than that of sulfuric acid, the amount of sodium sulphate used is the largest, which is why the ChF of sodium sulphate is almost the same as that of sulfuric acid. Hydrogen peroxide has a certain carcinogenicity, due to its instability, but it is still considered as a green and environmentally friendly additive since its products of decomposition are oxygen and water.

Compared with the experimental data, the toxicity prediction data obtained by QSAR model have prediction uncertainty. Figure 3 shows the ChF uncertainty of calculated results of each process segment. The overall uncertainty accounting for $20.2 \%$ of the total ChF $(4.40 \mathrm{E}+06$ I to $5.38 \mathrm{E}+06$ I). The uncertainty of scouring process was the most affected by the prediction data. In the scouring process, the proportion of uncertain value in the process was more than $54 \%(5.64 \mathrm{E}+05$ I to $9.93 \mathrm{E}+05$ I). Carbonization process was less affected by the uncertainty of prediction data, only $27.4 \%(4.86 \mathrm{E}+02$ I to $6.40 \mathrm{E}+02 \mathrm{I})$.
Because the ChF of dyeing process was so large that the uncertainty has little impact on it $(3.82 E+06$ I to $4.38 \mathrm{E}+06 \mathrm{I}$ ), although the uncertainty values of dyeing and scouring processes were in the same order of magnitude. The two processes of bleaching and finishing were not affected by the uncertainty from the prediction data, because the toxicity data of the two processes in the accounting inventory were the experimental data.

\section{CONCLUSIONS}

The chemical pollutants discharged in the process of wool textile production have severe impact on biological health and ecological environment. ChF can quantify environmental load from qualitative perspective and control pollution from the original production processes. In this paper, the ChF of dyed woollen yarn were quantified and assessed. The total ChF of selected 1 ton of woollen yarn was $4.89 \mathrm{E}+06 \mathrm{I}$. The dyeing process caused the most severe ecotoxicity impact $(4.10 \mathrm{E}+06 \mathrm{I})$, followed by scouring $(7.79 \mathrm{E}+05 \mathrm{I})$. The main reason is that a huge amount of levelling agent was used in the dyeing process to control the dyeing speed and transfer the dyes, and a huge amount of scouring agent was used in scouring process to remove natural fats in raw wool. The ChF of the finishing, carbonization, and bleaching stage were much smaller than those of the above two processes.

The discharged NPE (1.37E+06 I) caused the most severe ecotoxicity impact on the environment due to its high bioaccumulation and high toxicity to ecosystem, followed by sulfuric acid (1.03E+06 L). Sodium chloride and hydrogen peroxide were the two substances that caused the least environmental load in this study. The main reason is that the toxicity of sodium chloride is very low and hydrogen peroxide is easy to decompose. It is considered as a green and 
environmentally friendly additive as its products of decomposition are oxygen and water.

This study also analysed the uncertainty of calculated results due to the toxicity prediction data. The overall uncertainty accounted for $20.2 \%$ of the total ChF. The uncertainty of scouring process was the largest, which contributed more than $54 \%$ of the total ChF. The data used in the dyeing and scouring processes was experimental data, so they were not affected by the uncertainty of the prediction data.

ChF meet the biological and ecosystem health-oriented policy, so ChF theory can provide policy-making basis for related departments. The results of calculated ChF can help textile enterprises identify priority pollution and show the priority order of improvement. The way of quantitative evaluation of products and processes can guide enterprises to carry out targeted technical improvement and material selection.

At present, the quantification of chemical pollution in textile industry is facing some challenges. The formulation of many auxiliaries is opaque, and the main components are difficult to be determined. An efficient and transparent ChF database is needed. When considering regional differences, it is difficult to obtain toxicity indicators based on local species. The application of $\mathrm{ChF}$ in current research is mainly direct ChF, while indirect ChF need further study.

\section{ACKNOWLEDGEMENTS}

The authors are grateful to the Zhejiang Provincial Natural Science Foundation for providing funding supports to this research through projects LY20G030001, LY21G030004, Science and technology innovation activities of university students in Zhejiang Province (2020R406074, 2019R406059).

\section{REFERENCES}

[1] Japan Chemical Fibers Association (JCFA), Chemical fiber production trends at home and abroad, 2018, Available at: https://www.jcfa.gr.jp/mg/wp-content/uploads/2016/06/28847b7ba9649653e7ea83dc9474f521.pdf [Accessed on October 2019]

[2] Sun, R.Z., The current situation and problems of the development of textile industry, 2018, Available at: https://www.xianjichina.com/news/details_65513.html [Accessed on October 2019]

[3] Zhang, H.C., A Truth of Overall Positive Growth of the Global Textile Industry, In: Fiber Industry Sight, 2019, 523, 3, 103-104

[4] Zhang, J., The present situation and development of textile chemical industry in China, In: Dye Finis, 2002, 40, 9, $12-15$

[5] Wang, L.L., Wu, X.Y., Ding, X.M., Li, Y., Calculation and assessment of industrial water footprint of textiles and apparel, In: Journal of Textile Research, 2017, 38, 9, 162-167

[6] Villegas-Navarro, A., RammHrez-M.Y., Salvador-S, M.S., Gallardo, J.M., Determination of Wastewater LC50 of the Different Process Stages of the Textile Industry, In: Ecotoxicology \& Environmental Safety, 2001, 48, 1, 56-61

[7] Panko, J., Hitchcock, K., Chemical footprint ensuring product sustainability, In: Air \& Waste Management Association, 2011, 11-15

[8] Bjørn, A., Diamond, M., Birkved, M., Hauschild, M.Z., Chemical footprint method for improved communication of freshwater ecotoxicity impacts in the context of ecological limits, In: Environmental Science \& Technology, 2014, 48, 22, 13253-13262

[9] Sörme, L., Palm, V., Finnveden, G., Using E-PRTR data on point source emissions to air and water-First steps towards a national chemical footprint, In: Environmental Impact Assessment Review, 2016, 56, 102-112

[10] Du, C.H., Wang, Z.Y., Chen, J.W., Qiao, X.L., Li, X.H., Xie, H, B., Cai, X, Y., Chemical Footprint: Concepts, Research Progress and Challenges, In: Asian Journal of Ecotoxicology, 2016, 11, 2, 18-26

[11] Posthuma, L., Bjørn, A., Zijp, M.C., Birkved, M., Diamond, M.L., Hauschild, M.Z., Huijbregts, M.A.J., Mulder, C., Van de Ment, D., Beyond safe operating space: Finding chemical footprinting feasible, In: Environmental Science \& Technology, 2014, 48, 11, 6057-6059

[12] Zijp, M.C., Posthuma, L., Van de Meent, D., Definition andapplications of a versatile chemical pollution footprintmethodology, In: Environmental Science \& Technology, 2014, 48, 18, 10588-10597

[13] Du, C.H., Calculation and Characterization on Chemicals Footprint of Antibiotics in China, In: School of Environmental Science and Technology, Dalian University of Technology, 2017

[14] Hasanbeigi, A., Price, L., A technical review of emerging technologies for energy and water efficiency and pollution reduction in the textile industry, In: Journal of Cleaner Production, 2015, 95, 30-44

[15] Payet, J., Jolliet, O., Comparative Assessment of the Toxic Impact of Metals on Aquatic Ecosystems: The AMI Method, In: Life Cycle Assessment of metals: issues and research directions, 2004, 188-191

[16] Hauschild, M., GM-troph: A Low Data Demand Ecotoxicity Effect Indicator for Use in LCIA, In: The International Journal of Life Cycle Assessment, 2007, 12, 2, 79-91

[17] Van de Ment, D., Huijbregts, M.A.J., Calculating life-cycle assessment effect factors from potentially affected fraction-basedecotoxicological response functions, In: Environmental Toxicology and Chemistry, 2005, 24, 6, 1573-1578

[18] Eriksson, L., Jaworska, L., Worth, A.P., Cronin, M.T.D., McDowell, R.M., Gramatica, P., Methods for Reliability and Uncertainty Assessment and for Applicability Evaluations of Classification and Regression-Based QSARs In: Environmental Health Perspectives, 2003, 111, 10, 1361-1375

[19] Zhang, Z.G., Yin, H., Chen, Z.R., Development of levelling agent for acid dyes, In: Journal of Textile Research, 2005, 26, 4, 134-136 
[20] Derbyshire, A.N., Tristram, G.R., Chemical reactions between dyes and wool, In: Journal of the Society of Dyers and Colourists, 1965, 81, 12, 584-591

[21] International Wool Textile Organisation Wool LCA Technical Advisory Group., Guidelines for conducting a life cycle assessment of the environmental performance of wool textiles, In: International Wool Textile Organisation (IWTO), 2016, 16

[22] Wang, J.H., Li, Z.M., Research on the new technology of wool fibers carbon washing, In: Wool Textile Journal, $2013,41,4,57-60$

[23] Sun, L.H., New technology of wool carbonization and washing, In: China Textile Leader, 1987, 24, 7

[24] Zhou, S.Q., Lin, Y.Q., Advances of investigation on the pollution of environmental hormones, In: Environmental Pollution \& Control, 2004, 1, 25-27

[25] Hou, S.G., Xun, J., Wang, L., Sun, H.W., Dai, S.G., Liu, X.Y., Primary Study on Nonylphenol and Nonylphenol Polyethoxylates in Aquatic Environment at Lanzhou Reach of Yellow River, In: Environmental Chemistry, 2005, 24, 3, 250-254

[26] Wu, W., Wu, Y., Qu, J.H., Estrogenic activities and mutation effects of nonylphenol ethoxylates before and after biodegradation, In: China Environmental Science, 2003, 23, 5, 470-474

\section{Authors:}

\section{XIANG JI ${ }^{1,2}$, WEIRAN QIAN ${ }^{1,2}$, ZEJUN TIAN ${ }^{1,2}, \mathrm{YI} \mathrm{LI}^{3,4}$, LAILI WANG $2,4,5$}

${ }^{1}$ School of Fashion Design \& Engineering, Zhejiang Sci-Tech University, 310018, Hangzhou, Zhejiang, China e-mail: jixiang549961547@163.com(J.X.), QWeiran@163.com(Q.W.), 15003416393@sina.cn(T.Z.)

${ }^{2}$ Zhejiang Sci-Tech University, Engineering Research Center of Clothing of Zhejiang Province, 310018, Hangzhou, China

${ }^{3}$ Fashion Department of International United Faculty between Ningbo University and University of Angers/Faculty of Tourism and Culture, Ningbo University, Ningbo 315201, China e-mail: liyichina@yeah.net(L.Y.)

${ }^{4}$ Silk and Fashion Culture Research Center of Zhejiang Province, Zhejiang Sci-Tech University, 310018, Hangzhou, Zhejiang, China

${ }^{5}$ Zhejiang Academy of Ecological Civilization, Hangzhou 310018, China

\section{Corresponding author:}

LAILI WANG

e-mail: wangll@zstu.edu.cn 